\begin{tabular}{|l|l|l|l|}
\hline & & $1 . \operatorname{ECN} 640493$ \\
ENGINEERING CHANGE NOTICE & Page 1 of 2 & $\begin{array}{l}\text { Proj......................... } \\
\text { ECN }\end{array}$ \\
\hline
\end{tabular}

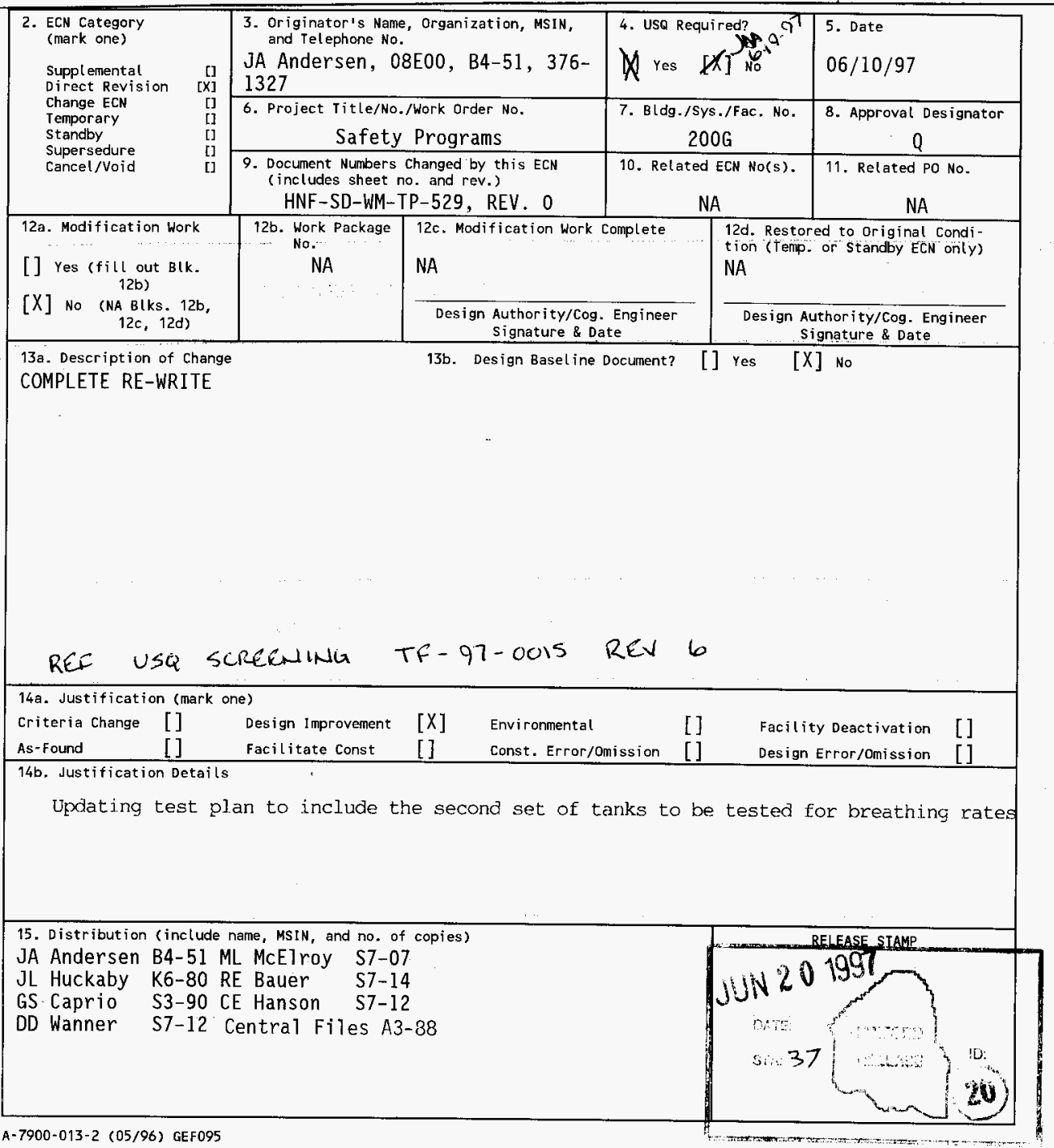




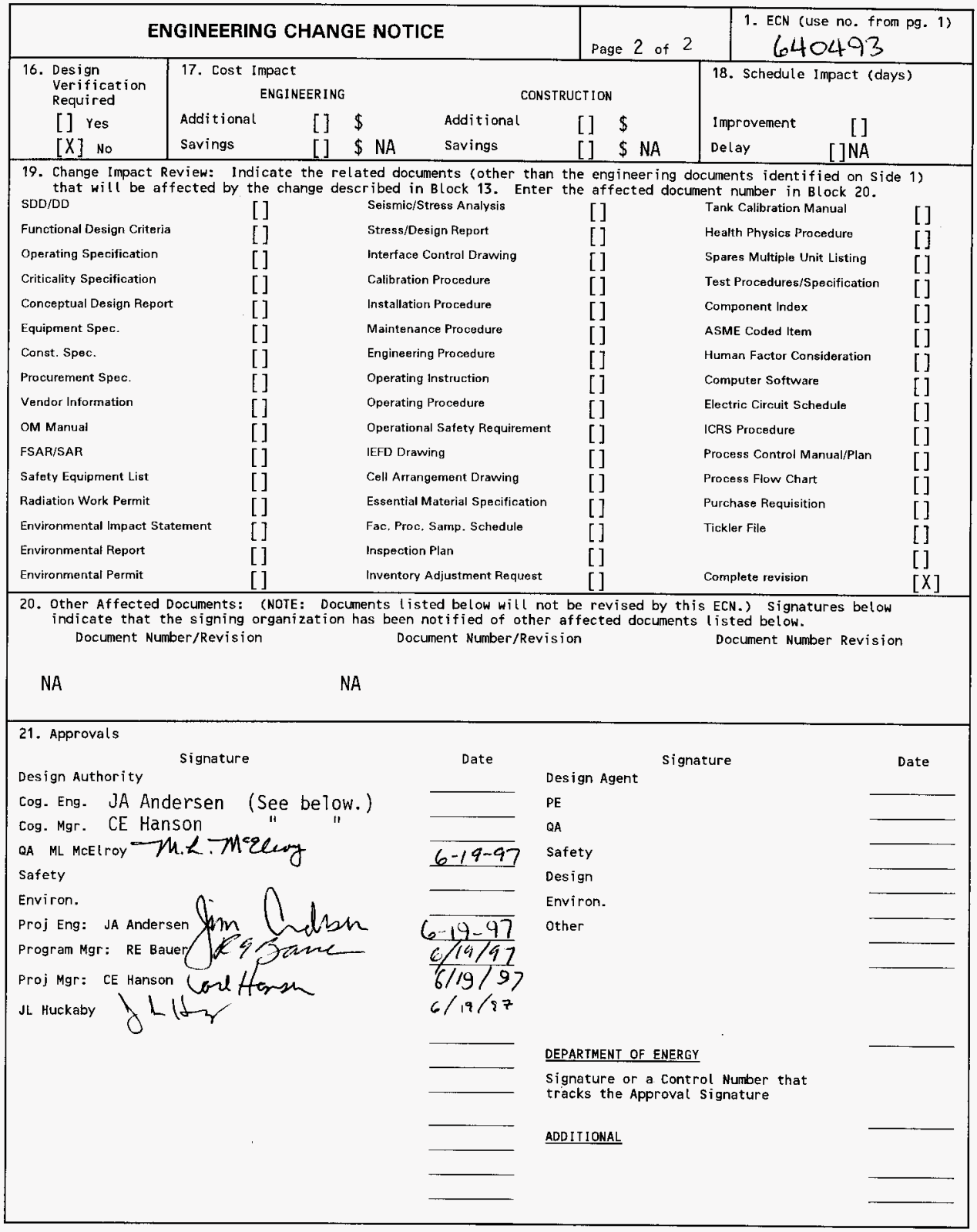




\section{Test Plan for Determining Breathing Rates in Single Shell Tanks Using Tracer Gases}

\section{JA Andersen}

SGN Eurisys Services Corporation, Richland, WA 99352

U.S. Department of Energy Contract DE-AC06-96RL13200

$$
\begin{aligned}
& \text { EDT/ECN: } 640493 \text { UC: } 2070 \\
& \text { Org Code: 08E00 Charge Code: N2012 } \\
& \text { B\&R Code: EW3120074 Total Pages: }{ }_{-22}^{22} 20
\end{aligned}
$$

Key Words: Breathing rates, tracer gas, single shell tanks, risers, headspace.

Abstract: This test plan specifies the requirements and conditions for the injection of tracer gases into eight tanks. Eight single shell tanks shall be injected with inert tracer gas, Helium (He), and then samples taken periodically to measure breathing rates. The eight tanks to be tested are; A-101, $\mathrm{AX}-102, \mathrm{AX}-103, \mathrm{BY}-105, \mathrm{C}-107, \mathrm{U}-103$ (tested once in the winter and will be tested once in the summer), and U-105. The headspace of these tanks shall be sampled and analyzed periodically to obtain breathing rate information. TRADEMARK DISCLAIMER. Reference herein to any specific commercial product, process, or service by
trade name, trademark, manufacturer, or otherwise, does not necessarily constitute or imply its
endorsement, recommendation, or favoring by the United states Government or any agency thereof or its contractors or subcontractors.

Printed in the United States of America. To obtain copies of this document, contact: Document Control Services, P.0. Box 950, Mailstop H6-08, Richland WA 99352, Phone (509) 372-2420;

Fax (509) 376-4989.
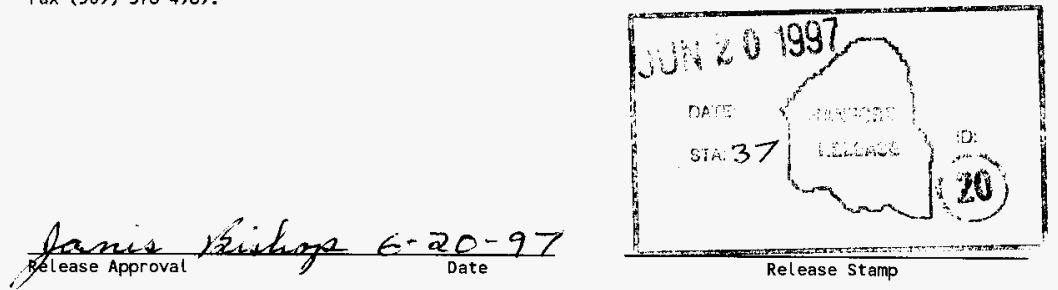

\section{Approved for Public Release}


(2) Title

TEST PLAN FOR DETERMINING BREATHING RATES IN SINGLE SHELL TANKS (SST) USING TRACER GASES

CHANGE CONTROL RECORD

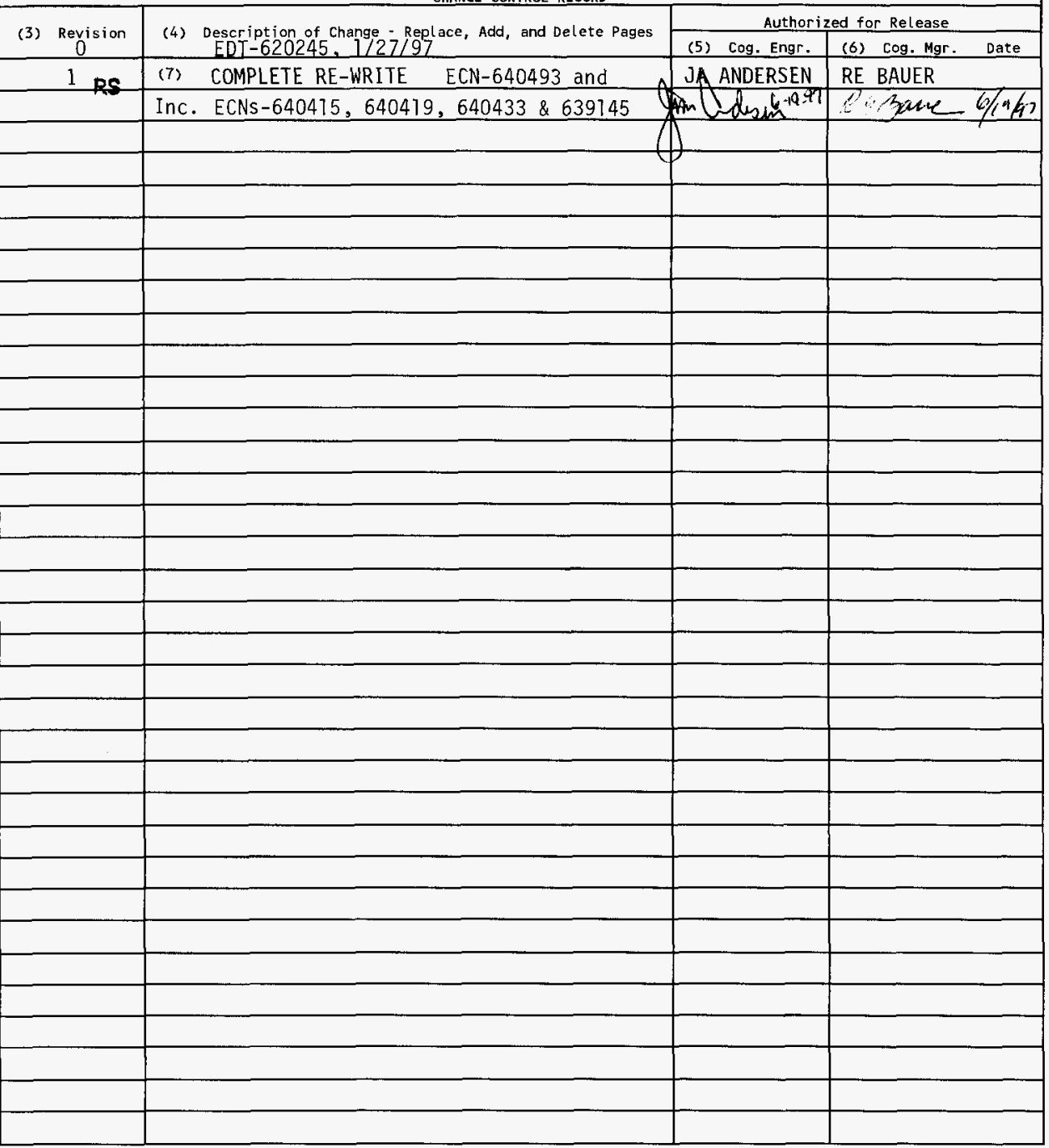




\title{
TEST PLAN FOR DETERMINING BREATHING RATES IN SINGLE SHELL TANKS USING TRACER GASES
}

\author{
J. A. Andersen \\ SGN Eurisys Services Corporation \\ June 1997 \\ Revision 1
}




\section{TABLE OF CONTENTS}

$1.0 \quad$ INTRODUCTION

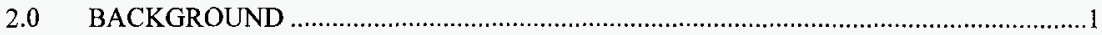

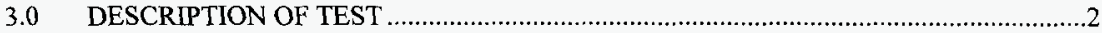

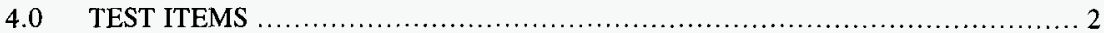

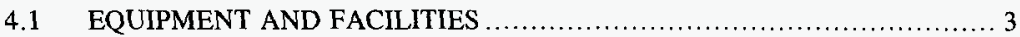

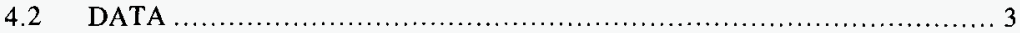

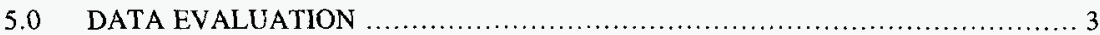

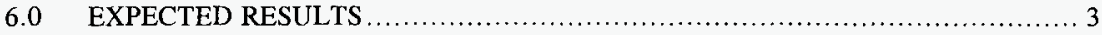

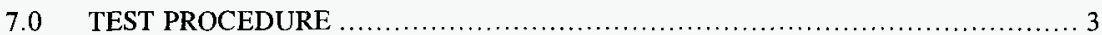

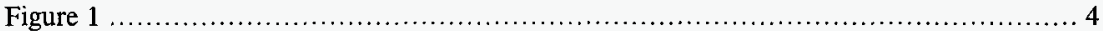

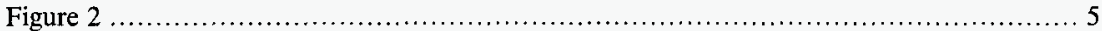

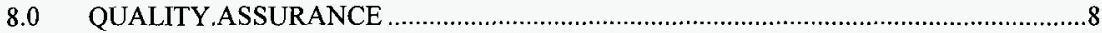

$9.0 \quad$ SAFETY

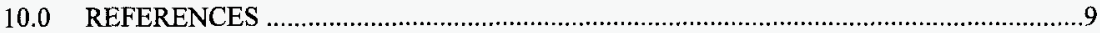

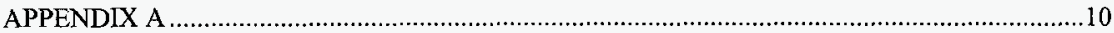

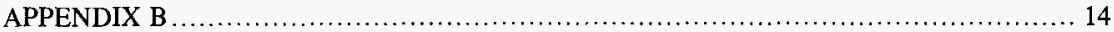




\section{TEST PLAN FOR DETERMINING BREATHING RATES IN SINGLE SHELL TANKS (SST) USING TRACER GASES}

\subsection{INTRODUCTION}

This test plan specifies the requirements and conditions for the injection of tracer gas (Helium (He)) into single shell tanks to determine breathing rates using periodic sampling. The eight tanks which have been selected at the time this Test Plan was developed are A-101, AX-102, AX-103, BY-105, C-107, U-103 (U-103 is counted twice, once during the winter months and once during the summer), and U-105. Other tanks to be sampled will be assigned by Pacific Northwest National Laboratory (PNNL) at a later date in the study process as resources allow, the document shall be revised as required.

The sampling of headspace for each of these tanks shall be performed using available risers or the Standard Hydrogen Monitoring System (SHMS) cabinet as available. The tank farm vapor cognizant engineer shall assign the injection and sample testing point for each tank and document the point in the field work package. SUMMA ${ }^{\mathrm{TM} 1}$ canisters, equipped in-line with dual particulate air filters and two silica gel sorbent traps will be used to collect the gas samples. The purpose of dual particulate air filters is to ensure no radioactive particulates are transferred to the SUMMA $^{\mathrm{TM}}$ canisters. The silica gel sorbent traps will effectively eliminate any tritiated water vapor that may be present in the sample gas stream. PNNL shall supply the tracer gases injection system and shall perform the analysis on the headspace samples. TWRS Characterization project shall inject the tracer gas and perform the sampling. Refer to Engineering Task Plan HNF-SDTWR-ETP-002 for a detailed description of the responsibilities for this task.

\subsection{BACKGROUND}

The primary goal of this activity is to use tracer gas to measure breathing rates of passively ventilated single shell tanks. Proof of concept for tracer gas injection was performed on tank S102 to determine breathing rates and mixing characteristics. The testing of tank S-102 used Helium and Sulfur Hexaflouride (SF6) as tracer gases. Results from the initial testing of tank S102 indicated both tracer gases to be effective for determining breathing rates. Document WHCSD-WM-TP-492 describes the testing process and how it was conducted. Subsequent testing in tanks AX-103 and C-107 revealed that SF6 was not as reliable as helium as a trace gas and therefore use of SF6 for breathing has been discontinued.

Development and application of the tracer gas breathing rate measurement technique has been accomplished by following a series of planned test. These tests and the test plan used to specify

\footnotetext{
${ }^{1}$ SUMMA ${ }^{\mathrm{TM}}$ trade mark of Moletrics, Inc.
} 
the test requirements are listed in Table 1. It is anticipated that test specification for future breathing rate measurements will be by revision of this test plan.

\begin{tabular}{|l|l|l|}
\hline \multicolumn{1}{|c|}{ Tank } & \multicolumn{1}{c|}{ Test Plan } & \multicolumn{1}{c|}{ Test Period } \\
\hline S-102 & WHC-SD-WM-TP-492, Rev 0 & $9 / 96-2 / 97$ \\
\hline & & \\
\hline U-103 (Winter Period) & HNF-SD-WM-TP-529, Rev 0 & $2 / 97-5 / 97$ \\
\hline C-107 & HNF-SD-WM-TP-529, Rev 0 & $2 / 97-4 / 97$ \\
\hline BY-105 & HNF-SD-WM-TP-529, Rev 0 & $2 / 97-5 / 987$ \\
\hline AX-103 & HNF-SD-WM-TP-529, Rev 0 & $2 / 97-3 / 97$ \\
\hline & & \\
\hline AX-102 & HNF-SD-WM-TP-529, Rev 1 & $6 / 97-8 / 97$ (Planned) \\
\hline A-101 & HNF-SD-WM-TP-529, Rev 1 & $6 / 97-8 / 97$ (Planned) \\
\hline U-103 (Summer Period) & HNF-SD-WM-TP-529, Rev 1 & $7 / 97-8 / 97$ (Planned) \\
\hline U-105 & HNF-SD-WM-TP-529, Rev 1 & $6 / 97-8 / 97$ (Planned) \\
\hline
\end{tabular}

\subsection{DESCRIPTION OF TEST}

Helium will be injected into the headspace of the designated tank through the assigned riser as appointed by the tank farm vapor cognizant engineer. The flow rate of the tracer gas being injected into the tank will be controlled to less than $227 \mathrm{~L} / \mathrm{min}$ ( 8 CFM) by the use of an orifice.

Prior to the tracer gas injection, a set of two baseline SUMMA ${ }^{\mathrm{TM}}$ canister samples will be collected from the head space through the injection/sample point. These samples will become the baseline samples for that tank. Prior to the baseline samples being taken the system shall be purged using a Combustible Gas Meter (CGM) or Organic Vapor Monitor (OVM) for five minutes. Approximately 24 hours after the tracer gas injection is complete; another set of SUMMA ${ }^{\mathrm{TM}}$ canister samples will be taken. These will be considered time zero samples. This procedure will be repeated at 7 days after the tracer gas is injected. See section 7.C3 for detailed information concerning the sampling time line.

\subsection{TEST ITEMS}

Helium is inert (even in the radiation field of the headspace) and essentially insoluble in the waste. Helium is lighter than air, and should mix within the headspace similar to hydrogen. Because it is present in ambient air at about 4 ppmv injection of enough gas to raise the initial concentration to 2,000 ppmv would result in a measurable range spanning 3 orders of magnitude. This is adequate for the anticipated range of breathing rates. 


\subsection{EQUIPMENT AND FACILITIES}

The equipment needed for testing each tank is:

Tracer gas injection system (Figure $1 \& 2$ ).

10 available SUMMA ${ }^{\mathrm{TM}}$ Canisters supplied by PNNL.

20 Silica gel sorbent traps $(8 \mathrm{~mm} 450 \mathrm{mg}$ ) supplied by vapor team.

10 Particulate air filters for SUMMA ${ }^{\mathrm{TM}}$ canisters supplied by vapor team.

\subsection{DATA}

The test data that will be required is identified in the data sheet in Appendix B.

\subsection{DATA EVALUATION}

The evaluation and reporting of the data from the SUMMA ${ }^{\mathrm{TM}}$ canisters shall be performed by PNNL.

\subsection{EXPECTED RESULTS}

1) Injection of tracer gas will bring initial concentration close to target starting concentration.

2) Tracer gas concentration will decay with time as the tank breathes.

3) Measured ventilation rates will be in the range of $28.3-566 \mathrm{~L} / \mathrm{min}(1-20 \mathrm{CFM})$.

\subsection{TEST PROCEDURE}

Baseline Sample Procedure (Refer to Figure 1)

7.A1 Collect two SUMMA ${ }^{\mathrm{TM}}$ canister samples from the sample line per LO-80-403 and steps 7.A2 through 7.A17. Record the date and time of sample collection in the data sheet in Appendix A.

7.A2 Connect a Single Ended, shut-off, quick disconnect body (Swagelok part \#QC4) to the assigned attachment point for the sample.

7.A3 Connect (in series) two particulate air filters and two silica gel sorbent traps to the quickdisconnect installed on the sample line. The particulate air filters (F1) shall be closest to the riser with the silica gel sorbent traps (F2) on the down stream side of the air filters.

Note: The silica gel sorbent traps must be replaced after each SUMMA ${ }^{\mathrm{TM}}$ canister sample set. 


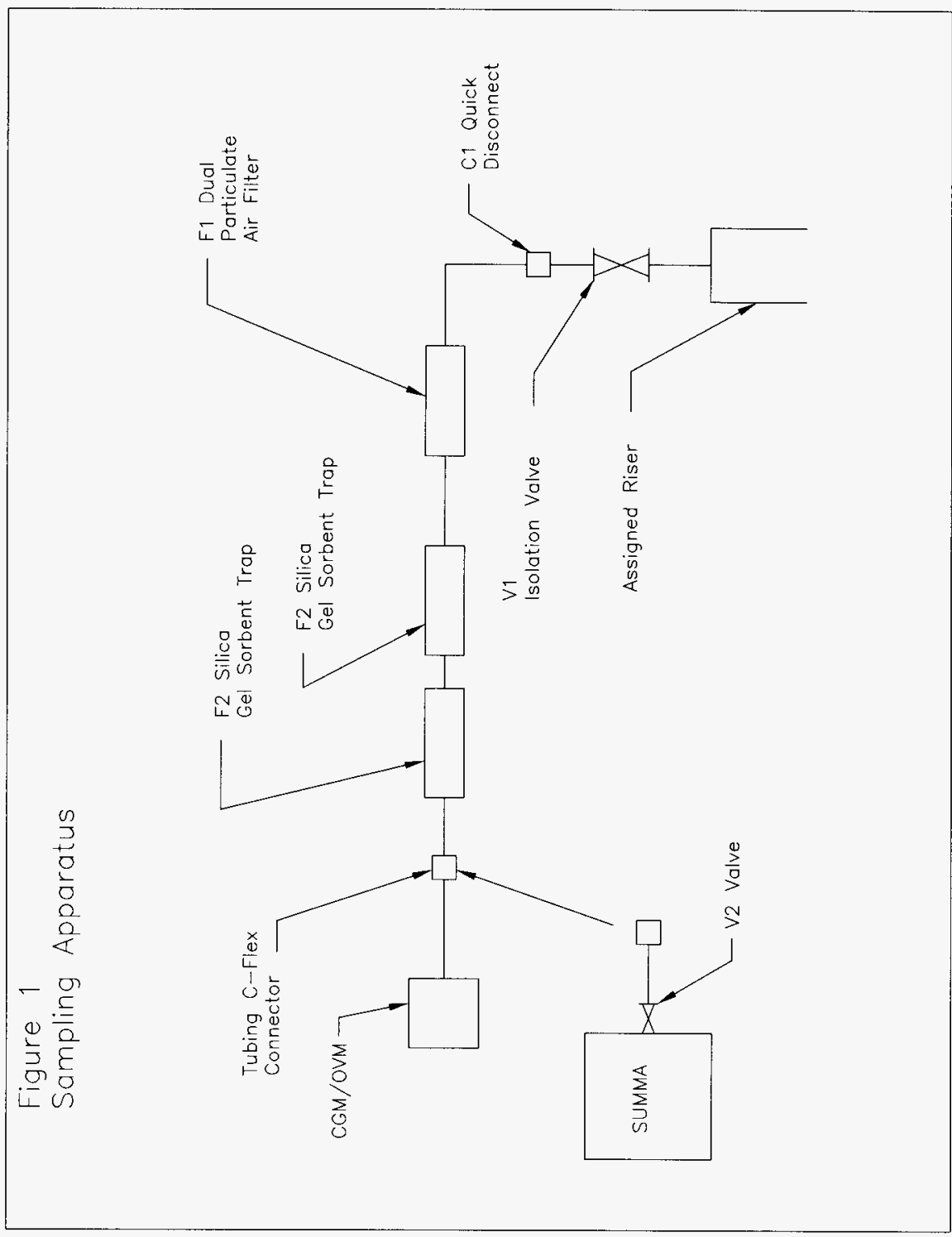

Page 4 


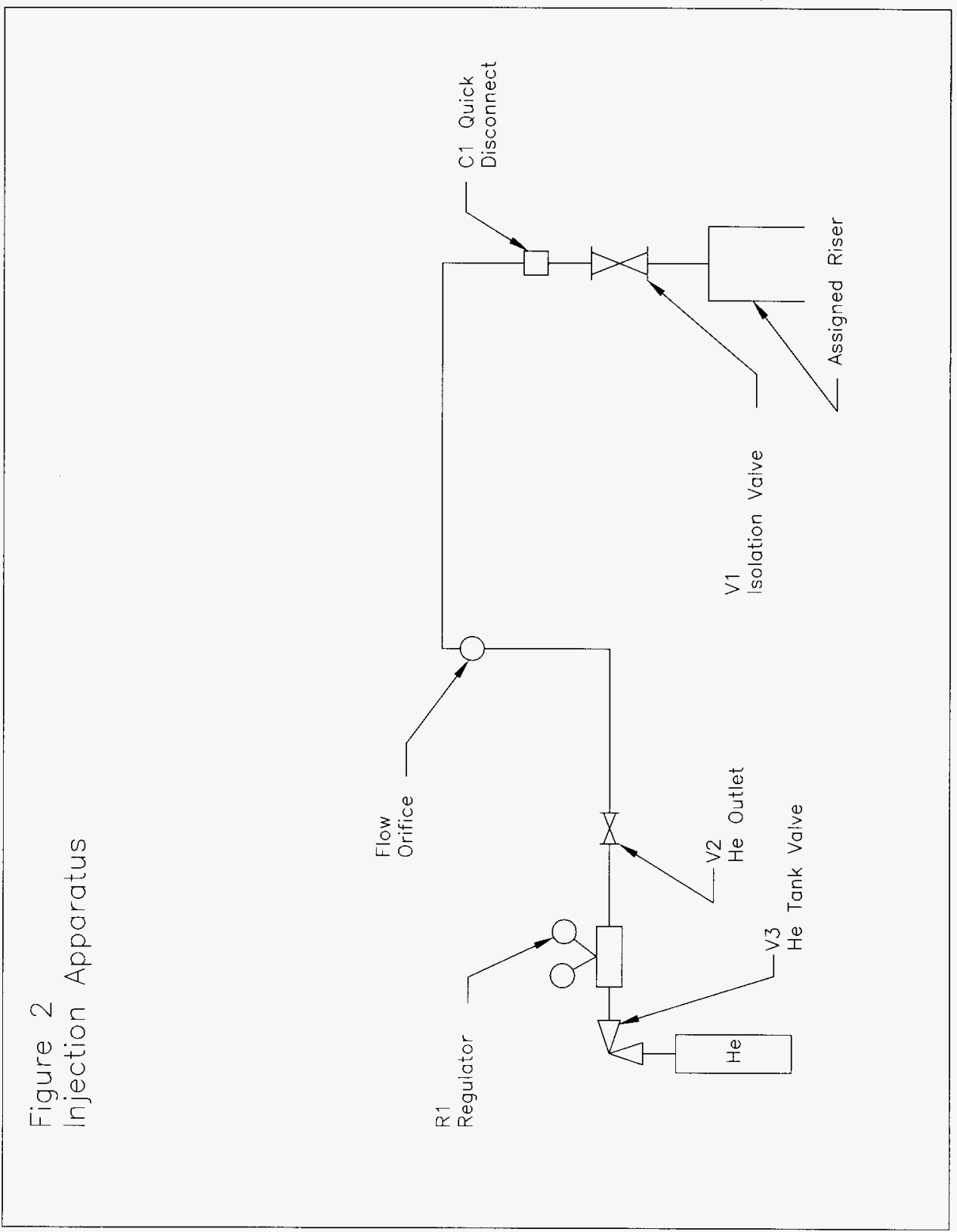

Page 5 
7.A4 A short piece of $\mathrm{c}$-flex should be placed on the downstream side of the silica gel sorbent traps (F2). This will allow for the quick connection between the CGM/OVM and SUMMA $^{\mathrm{TM}}$ canisters.

7.A5 Connect the CGM/OVM to the c-flex.

7.A6 Open the sample line isolation valve, V1.

7.A7 Purge the sample line for 5 minutes using the CGM/OVM. For the 24 hour sample only the purge shall be a minimum of 20 minutes. For all other sampling periods a 5 minute purge shall be used.

7.A8 Close the isolation valve, Vl.

7.A9 Disconnect the CGM/OVM from the c-flex and connect the SUMMA ${ }^{\mathrm{TM}}$ canister downstream of the silica gel traps.

7.A10 Open isolation valve, V1.

7.All Collect the SUMMA ${ }^{\mathrm{TM}}$ sample per LO-80-403.

7.A12 Close isolation valve, V1.

7.A13 Disconnect the canister from the c-flex and then connect the second canister.

7.Al4 Open isolation valve, $\mathrm{V} 1$.

7.Al5 Collect the second SUMMA ${ }^{\mathrm{TM}}$ sample per LO-80-403.

7.Al6 Close isolation valve, V1.

7.AI7 Label and control the two SUMMA ${ }^{\mathrm{TM}}$ canister samples per Appendix A.

Tracer Gas Injection Procedure (Refer to Figure 2)

7.B1 Connect the tracer gas injection system to the sample line (as shown in figure 2) at connection $\mathrm{Cl}$.

7.B2 Open the valve (V3) located on the He cylinder and adjust the two stage regulator until the low pressure side of the regulator reads approximately 40 psig.

7.B3 Record the high-pressure reading of the He cylinder in Appendix B.

7.B4 Open the isolation valve (V1) located on the riser. 
7.B5 Open the valve (V2) at the outlet of the He cylinder. Record the date and time in the data sheet located in Appendix B.

7.B6 The Helium cylinder contents shall be injected into the tank, valve (V3) located on the Helium cylinder shall be closed prior to the high pressure reading a display of 25 psig. Record the high pressure reading and the time in Appendix A.

A-101 Exception. The amount of Helium injected into tank A-101 will be less than an entire cylinder, the amount of Helium injected shall be specified in the field work package.

7.B7 Close the outlet valve (V2) on the He cylinder.

7.B8 Close the isolation valve (V1) and disconnect the tracer gas injection system.

\section{Post Injection Sampling Procedure}

7.Cl After approximately one day, replace the silica gel sorbent traps and dual particulate air filters (F1 and F2) and repeat steps 7.Al through 7.A17.

7.C2 Collect two SUMMA ${ }^{\mathrm{TM}}$ canister samples from the sample point per LO-80-403 and steps 7.Al through 7.A17. Record the date and time of sample collection in the data sheet in Appendix B.

7.C3 Repeat steps 7.Cl and 7.C2 to collect samples at the following approximate intervals:

+7 days following tracer gas injection

+30 days following tracer gas injection

+90 days following tracer gas injection

The sampling intervals that have been described are only a guideline. The actual dates will vary depending on the previous sample set. If a tank is breathing a rate higher than anticipated the sampling interval will be adjusted accordingly, less number of days between sample sets. Conversely, a tank breathing at a slower rate than anticipated may have more days between sample sets then the guideline.

\section{U-103 Winter Sample Exception}

During the U-103 tracer gas sampling period there will be a push mode sample taken from $\mathrm{U}-103$. One additional tracer gas sample will be taken to determine if push mode sampling has any affect on tank breathing rates. As a result samples will be collected on the following timetable for U-103 winter samples only: 
+7 days following tracer gas injection

+30 days following tracer gas injection (pre-push mode sample)

+ TBD days following tracer gas injection (post-push mode sample)

+90 days following tracer gas injection

Note: The time line that has been established is approximate. Sampling events are not required to take place on the exact date. There is flexibility built into each of these dates, the actual sampling date will be selected based on scheduling availability and the results of the previous sampling event. For example if the breathing rates of the one-day sample were high, the seven-day sample could be taken on day three. Conversely, if the one day sample showed low breathing rates the seven day sample could be taken on day ten.

7.C4 Record the date and time of sample collection in the data sheet in Appendix A.

7.C5 Label and control the SUMMA ${ }^{\mathrm{TM}}$ canister samples per Appendix A.

\subsection{QUALITY.ASSURANCE}

No QC hold points are required for this testing. The PNNL Vapor Analytical Laboratory procedure's PNL-TVP-07 for SUMMA ${ }^{\mathrm{TM}}$ canister cleaning and PNL-TVP-02 for SUMMA ${ }^{\mathrm{TM}}$ canister shipping, receiving, and handling (chain-of-custody) shall be used. Analyses for $\mathrm{He}$ shall be performed by PNNL at a Quality Assurance Impact Level (QA-IL) Two by mass spectrometry. Preliminary results shall be reported via electronic mail, as they become available. The PNNL QA Plan is "FY97 Flammable Gas QA Plan" with document number MCS-027 rev. 2.

Quality assurance shall be required for the approval of the engineering task plan, test plan, and the work packages.

\subsection{SAFETY}

There is no anticipated safety impact with this testing. The tracer gas injection system has been setup so that it is not possible to over pressurize the tank and all samples will be protected from contamination by double Particulate air filters. The equipment being used for the testing is classified as "General Service" per WHC-CM-4-46, Sect 9.0. An Unreviewed Safety Question (USQ) screening has been completed for this testing and will be included in the JCS work package. 


\subsection{REFERENCES}

WHC, 1996, Test Plan for Measuring the Breathing Rate of Tank S-102 by Use of Tracer Gases, WHC-SD-WM-TP-492, Revision 0, Westinghouse Hanford Company, Richland, Washington

HAS, 1997, Sample Chain of Custody, Acceptance, and Disposal, LO-090-450, Revision B-1, Hanford Analytical Services (Rust Federal Services and Numatec Hanford Co.), Richland, Washington

HAS, 1997, Collection of SUMMA Canisters, LO-080-403, Revision A-0, Hanford Analytical Services (Rust Federal Services and Numatec Hanford $\mathrm{Co}$.), Richland, Washington

WHC, 1996, Safety Analysis Manual, WHC-CM-4-46, Revision 21, Westinghouse Hanford Company, Richland, Washington

PNNL, 1995, Shipping, receiving, and Handling Procedure for PNL Waste Tank Samples, PNLTVP-07, Revision 1, Pacific Northwest National Laboratory, Richland, Washington

PNNL, 1994, Cleaning SUMMA Canisters and the Validation of the Cleaning Process, PNLTVP-02, Revision 0, Pacific Northwest National Laboratory, Richland, Washington

PNNL, 1996, QA Plan for PNNL Flammable Gas Project, MCS-027, Revision 2, Pacific Northwest National Laboratory, Richland, Washington 


\section{Appendix A}

\section{Radiation Screening}




\section{A-1 RADIATION SCREENING}

The Vapor Team (VT) shall maintain all vapor samples under chain-of-custody requirements while performing a radiological survey of certain items used during sampling. Surveys are conducted to assure compliance with Department of Transportation (DOT) shipping regulations and offsite laboratory acceptance criteria. If the limits in Table A are exceeded the survey samples will be re-counted every few days until the activity level drops below the limits in Table A. If the survey samples won't drop below limits in Table A (i.e., Cs-137), the program office will provide guidance to the VT for sample media handling (dispose, ship to PNNL as radioactive material, etc.).

The results from the radiation screening are submitted to and shall be evaluated by the VT to ensure the samples meet the analytical criteria specified in Table A. VT shall provide a Format II report to each analytical laboratory to specify survey results.

Table A. Limits for Acceptable Radionuclide Activity Levels

\begin{tabular}{|l|c|c|c|c|}
\hline \multicolumn{1}{|c|}{ Organization } & Total $\alpha$ & Total $\beta / \gamma$ & Total $\alpha / \beta / \gamma$ & Units \\
\hline $\begin{array}{l}\text { PNNL Vapor } \\
\text { Laboratory }\end{array}$ & $<5$ & $<15$ & N/A & PCi $/ g$ \\
\hline WHC-CM-2-14 & N/A & N/A & $<2000$ & $\mathrm{pCi} / \mathrm{g}$ \\
\hline
\end{tabular}

\section{A-2 SAMPLING OPERATIONS}

VT shall provide unique sample label and identification numbers to the laboratories. Each sample identification number shall have the following format:

VXXXX-WYY-LLLL

where,

$\mathrm{XXXX}=$ unique number assigned to the sampling event,

$\mathrm{W}=$ a letter code indicating the day of a multi-day sampling event,

$Y Y=a$ 2-digit sample code found in the data sheet at the end of this Appendix.

$L L L L=$ a special lab assigned code.

Once the sample collection media has been received by VT from the laboratory, it shall remain in the physical control of the custodian, locked in a secure area, or prepared for shipping with tamper evident tape under conditions specified on the chain-of-custody form and in accordance with laboratory operating procedure LO-90-450 "Chain-of-Custody, Acceptance, and Disposal. 
Applicable operating procedures for the tank vapor space sampling activities are contained in the appropriate work package. Vapor samples, trip blanks, and field blanks are to be collected in accordance with operating procedure LO-80-403 "Collection of SUMMA Canister Samples; and shipped to the laboratory in accordance with Hazardous Material Packaging and Shipping, WHCCM-2-14.

All sampling activities shall be documented in controlled field logbooks maintained by sampling personnel (VT) and shall contain, but are not limited to:

- Identification of tank and riser number and photographs of the sample location in which the sampling is conducted,

- If any anomalies are observed, corresponding sample identification numbers, flow rates, pressures, temperatures, and other operational parameters affecting the sample,

- Any conditions that the sampler may observe during the sampling event (i.e., odors, nearby machinery in operation, etc.),

- Names and titles of personnel involved in the field activity and their responsibilities,

VT is responsible for documenting any problems and procedural changes affecting the validity of the sample in a controlled field notebook and shall enter this information in the comment section of the chain-of-custody form for addition to the data reports.

\section{A2.1 U-103 WINTER SAMPLE NUMBERING}

The sampling of U-103 may have on additional set of samples taken, this is based on the push mode samples being taken sometime during the tracer gas sampling period. Because there will be one additional sample set taken the U-103 sample numbering will be unique from the described sample numbering in this test plan. The sampling for $\mathrm{U}-103$ will provide for a baseline sample, tracer gas injection, +24 hour, +7 day, +30 day (pre-push mode sample), floating sample (post-push mode sample), and +90 day sample. The numbering for the U-103 sampling will be as follows: 


$\begin{array}{lll}\text { Sample Set } 1 & \text { A01 } & \\ & \text { A02 } & \\ \text { Sample Set 2 (+24 HR) } & \text { B01 } & \\ & \text { B02 } & \\ \text { Sample Set } 3(+7 \text { Days }) & \text { C01 } & \\ & \text { C02 } & \\ \text { Sample Set } 4 \text { (+30 Days) } & \text { D01 } & \text { (Pre-Push Mode) } \\ & \text { D02 } & \\ \text { Sample Set 5 (Floating) } & \text { E01 } & \text { (Pre-Push Mode) } \\ & \text { E02 } & \\ \text { Sample Set 6 (+90 Days) } & \text { F01 } & \\ & \text { F02 }\end{array}$

\section{A-3 SAMPLE CUSTODIAN}

The sample custodian is the designated VT cognizant scientist or assisting scientific technician, lead sampler, or laboratory scientist or technician who signs the received by block on the chainof-custody form. Transfer of custodianship occurs when the custodian signs the relinquished by block on the chain-of-custody form and releases the sample(s) to the new custodian signature.

\section{A-4 PHYSICAL CONTROL}

Physical control of a sample includes being in the sight of the custodian, in a room that shall signal an alarm when entered, or locked in a cabinet.

\section{A-5 FORMAT II REPORTING}

Results of the Laboratory's radiological survey shall be reported by the VT as Format II reports to PNNL, listing the picocuries per sample ( $\mathrm{pCi} / \mathrm{g} / \mathrm{sample}$ ) for each sample submitted for analysis. This Format II report should also provide the sample collection sequence and volumes, verification of trip and field blank use, and any anomalous sampling conditions. This report is to accompany, if possible, the shipment of samples. Alternatively, this sampling report may be transmitted by FAX to PNNL within 48 hours after the samples have been shipped. The radiological survey must accompany the samples, or be transmitted before samples are shipped to PNNL. 
Appendix B

Data Sheets 


\section{DATA SHEET}

\begin{tabular}{||l|c|l|l|l||}
\hline & Sample No. & Date & Time & Recorded By \\
\hline Sample Set 1 & A01 & & & \\
\hline Tracer Gas Injection: & A02 & & & \\
\hline Start Pressure: & N/A & & & \\
\hline Stop Pressure: & N/A & & & \\
\hline Sample Set 2 (+24 HRS) & B01 & & & \\
\hline Sample Set 3 (+7 Days) & B02 & & & \\
\hline & C01 & & & \\
\hline Sample Set 4 (+30 Days) & D01 & & & \\
\hline & D02 & & & \\
\hline Sample Set 5 (+90 Days) & E01 & & & \\
\hline & E02 & & & \\
\hline
\end{tabular}




\section{DATA SHEET}

\begin{tabular}{|c|c|c|c|c|}
\hline & Sample No. & Date & Time & Recorded By \\
\hline \multirow[t]{2}{*}{ Sample Set 1} & $\mathrm{~A} 01$ & & & \\
\hline & $\mathrm{A} 02$ & & & \\
\hline Tracer Gas Injection: & N/A & & & \\
\hline \begin{tabular}{l|l} 
Start Pressure: & \\
\end{tabular} & N/A & & & \\
\hline \begin{tabular}{l|l} 
Stop Pressure: & \\
\end{tabular} & $\mathrm{N} / \mathrm{A}$ & & & \\
\hline \multirow[t]{2}{*}{ Sample Set 2 (+24 HRS) } & B01 & & & \\
\hline & $\mathrm{B} 02$ & & & \\
\hline \multirow[t]{2}{*}{ Sample Set 3 (+7 Days) } & $\mathrm{C01}$ & & & \\
\hline & $\mathrm{C} 02$ & & & \\
\hline \multirow[t]{2}{*}{ Sample Set 4 (+30 Days) } & D01 & & & \\
\hline & $\mathrm{D} 02$ & & & \\
\hline \multirow[t]{2}{*}{ Sample Set 5 (Floating) } & E01 & & & \\
\hline & E02 & & & \\
\hline \multirow[t]{2}{*}{ Sample Set 6 (+90 Days) } & F01 & & & \\
\hline & F02 & & & \\
\hline
\end{tabular}

